Journal of Management and Business Aplication

\title{
THE INFLUENCE OF EXTRACURRICULAR ACTIVITIES, TEACHER TEACHING STYLES AND LEARNING MOTIVATION ON LEARNING ACHIEVEMENT IN SMA SATYA DHARMA BALUNG JEMBER
}

\author{
Moh. Agus Riawan ${ }^{1}$ \\ Muhammad Firdaus ${ }^{2}$ \\ Kasiman $^{3}$ \\ Higher Education of Economic Mandala \\ Email: Narutoichigo7@gmail.com
}

\begin{abstract}
Every educational institution, wants every student to achieve satisfactory achievements, achievements achieved by students are the main measurement tool and hope for knowing the success of an education. To further improve student learning achievement, it needs several ways to support the process of achieving that goal, and among the ways that can be taken is to start the implementation of various extracurricular activities in each educational institution. Extracurricular activities are a series of programs for teaching and learning activities outside the programmed hours, which are intended to improve the perspective of students, to foster talent and interest and to serve the community. For example: in Scouting activities is a form of activity that many develop humanitarian and spiritual activities in socializing, including cleanliness of the environment, providing assistance to people who are in disasters, health and so on. The article is intended to investigate the extent to which teaching styles and student learning motivation influence partially and simultaneously on student achievement. The samples are 124 students out of 248 from class X and XI students Satya Dharma High School Balung Jember. Data obtained from questionnaires and documentation were analyzed by multiple regression techniques. The results show that the teacher's teaching style and student learning motivation contribute more to student achievement. However, learning motivation has more dominant influence on student learning achievement than the teacher's teaching style. But this research only discusses concepts and conclusions taken from the relevant researcher hypothesis before.
\end{abstract}

Keywords: extracurricular activities, teaching style, learning motivation and learning achievement

\section{INTRODUCTION}

One aspect of the teaching style is the style of leading the class means the way of teacher provides direction for the teaching and learning process. The teacher plays a very important role in the teaching and learning process. In learning process, a teacher must have an ability to modify the skills to be taught to fit the level of student's development. Through the teacher's teaching style, students are able to demonstrate perseverance in mastering subjects. Teacher is the leader in class for student. Although the teaching style of a 
teacher differs from one another during the learning process but they have the same purpose, that are to convey knowledge, to shape student attitudes, and to create skilled students in work. Aryanto (2010: 159-160) suggest that teachers those who often provide the exercises to understand material will produce better students compared to teachers who only explain and do not follow up continuously. This is because teaching and learning activities not only lie in the teacher but also students. Teaching and learning activities are dominated by teachers. Students just sit, be silent, listen, and accept whatever is given by the teacher, do not ask questions and do not raise problems. All the subject matter given by the teacher is swallowed thoroughly, without being processed in his soul, and without doubt the truth. This type of teaching style is less effective because students do not actively decide what must be accepted and students only believe in truth to teacher's words. Teacher is always right.

With the application of the curriculum and accompanied by a pleasant teacher teaching style can foster enthusiasm or motivation of students to learn a subject. Motivation for learning that arises in students is caused by aspirations or encouragement to get the expected results. Students who have highly motivated in learning make it possible to obtain high learning achievement, meaning that the higher the motivation, the intensity of the efforts to achieve the appropriate learning achievement.

Satya Dharma High School Balung Jember is a private higher education institution that is a favorite among private high schools, facilities and infrastructure, as a whole. this school is able to carry out the learning process. The success of learning achieved at Satya Dharma High School Balung Jember. High School is certainly inseparable from the competence or professionalism of the teacher in creating a pleasant teaching style in classroom, so that what he has tought can be fully accepted by students. However, according to information obtained from students of class X and class XI of Satya Dharma High School Balung Jember, it shows that not all teachers are able to apply the teaching style well according to the circumstances of the students. So it's not all material

The lessons delivered by the teacher can be accepted by students. Then it can reduce students' learning motivation. Therefore, this study intends to: 1) know and analyze simultaneously the influence of teacher teaching styles and student learning motivation on the learning achievements of students of class $\mathrm{X}$ and $\mathrm{XI}$ at Satya Dharma High School Balung Jember. 2) to know and analyze partially the influence of teacher teaching style and learning motivation on student learning achievement in class $\mathrm{X}$ and XI at Satya Dharma High School Balung Jember. The results of the hypothesis indicate that the teacher's teaching style and learning motivation simultaneously and partially have a significant influence on student learning achievement of students of class $\mathrm{X}$ and XI at Satya Dharma High School Balung, Jember. There are several theories about teacher teaching styles and student learning motivation, among others: Suparman (2010: 63) suggests that teaching styles are the methods used by teachers when teaching. Teaching According to Winkel (1996: 203) one aspect of teaching style is the style of leading the class means the way the teacher provides direction for the teaching and learning process. The division of leading style according to Kurt Lewin in Winkel (1996: 204), namely: A) authoritarian style, b) laissez-faire style, c) democratic style.

The understanding of learning according to Daryanto (2010: 2) is a business process carried out by someone to obtain new behavioral changes as a whole, as a result of his own experience in interacting with the environment. 
From the definition above, it can be concluded that learning is a process of change in a person as a result of interaction with the environment in meeting life's needs. Learning motivation according to Clayton Alderfer in Nashar (2004: 42) Learning motivation is the tendency of students in learning activities that are driven by the desire to achieve the achievement as many as possible. Then according to Nashar (2004: 42) learning motivation is an internal and external encouragement that causes a person (individual) to act or do the goals, so that student behavior changes are expected to occur.

From the opinion of experts above it can be concluded that the motivation of learning is a psychological condition that encourages students to learn with pleasure and study in earnest, which in turn will form a systematic student learning, full of concentration and can select the activities. The type of learning motivation are intrinsic and extrinsic motivation. Motivation function in learning according to Sardiman (2003: 85), there are three functions, namely: 1) encourage people to do, motivation in this case is the driving force of every activity to be done. 2) determine the direction of action, motivation can provide direction and activities to be done in accordance with the formulation of its purpose. 3) selecting actions, determining what actions should be done harmonious in order to achieve the goal, by setting aside actions that are not beneficial to the goal, 4) the drivers of business and achievement, good motivation of in learning will show good achievement . In other words, the diligent effort is mainly based on the motivation, then someone who learn will be able to reach a good achievement.

The mastery person of certain knowledge or skills in a subject, which is generally obtained from the value of the test or the number given by the teacher and referred to as learning achievement. If the score given by teachers is low, then someone's performance is considered low. If the score given by the teacher is high, then student achievement is considered high and is considered a student who is successful in learning. Based on the above description, the factors that can affect learning achievement are: 1) factors that originate from the learner, means that these factors originate within the student itself, which consists of: motivation, attention to the subjects occur, the level of acceptance and material reminders, the ability to apply what is learned, , reproducibility and ability

The teacher, this factor comes from outside the learner, includes: the ability to build relationships with the learner, the ability to move the interest of the lesson, the ability to explain, the ability to mention the subject matter taught, the ability to direct attention to the lesson Ongoing, ability to respond the reactions.

\section{RESEARCH METODS}

In this study, researchers use the type of quantitative research, means that research emphasizes the theory testing through measurement of research variables with numbers and perform analysis with statistical procedures. Sugiono in Amin (2016) As for the research design can be described as follows:

Figure 1 Thinking Process Framework

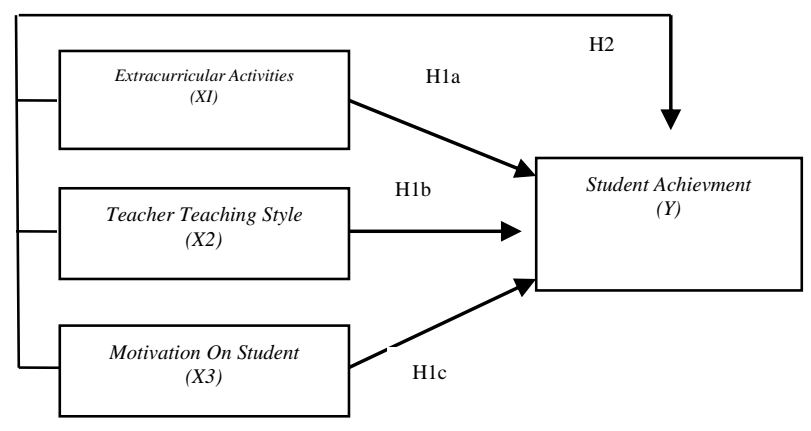


1. Extracurricular activities

In the book Self-Development Guide

Regulation of the Minister of National

Education No. 22 of 2006 also describes

the principles of extracurricular activities as follows:

a. Individual, is an extracurricular activities that suitable with the potential, talents, interests of each learner.

b. Choice, is an extracurricular activities in accordance with the wishes and followed by volunteer learners.

c. Active involvement, is extracurricular activities that requires full participation of learners.

d. Fun, is extracurricular activities in the preferred and exciting atmosphere of the students.

e. Work ethic, is extracurricular activities that build the spirit of learners to work well and succeed.

f. Social benefits, is extracurricular activities carried out for the benefit of the community.

2. Teacher Teaching Style (X1)

According Sunaryo (1989: 35) in Wahyudi (2010). Teachers' teaching styles basically include variations in voice, variations in limb movements and variations in teacher position movements in the classroom. By using this variation students will see as something energetic, passionate and all of them have relevance to student achievement.

3. Motivation (X2)

Motivation is a factor that affects the spirit and enthusiasm of employees to play an active role in the work process. The most famous motivational theory is the hierarchy of needs that Abraham Maslow expressed. The hypothesis says that in all human beings there are five levels of need (Maslow, in
Robbins, 2006), which is an indicator of:

a. Fisiologis, includes hunger, thirst, protection (food clothing), and other physical needs.

b. Security, including safety and protectionagainst physical and emotional losses.

c. Social, includes affection, belonging, acceptance, and friendship.

d. Award, includes self-respect factors such as self-esteem, autonomy, and achievement, as well as external respect factors such as status, recognition, and attention.

e. Self-actualization is the drive to become someone / something according to his ambition that includes growth, achievement of potential, and self-fulfillment.

4. Student achievement

Achievement learn by Hamalik (1994: 45 ) is a learning achievement in the form of a change in attitude and behavior after receiving a lesson or after learning something.

According Syah (1999: 144) is globally explain the factors that affect student learning. It is divided into three kinds, namely:

a. Internal factors (factors from within students), namely the state / condition of the physical and spiritual students.

b. External factors (factors from outside students), ie environmental conditions around students.

c. Factor approach to learning, namely the type of student learning efforts that include strategies and methods used by students to conduct learning activities mater - subject matter.

\section{Population}

Population that exist in this research is the entire class $\mathrm{X}$ and $\mathrm{XI}$ in SMA Satya 
Dharma Balung Jember consisting of 5 class $\mathrm{X}$, namely: class $\mathrm{X} 1$, class $\mathrm{X} 2$, class $\mathrm{X} 3$, class X4, class X5, class XI IPA1, XI IPA2, class XI IPS1 and class XI IPS2. With total population are 124 students. While for the sampling technique is done by purposive random sampling, that is taking the sample member from the population is done by taking into account the strata of active activity of absent in the population. So that the number of samples are 24 students.

\section{INTERPRETATION}

Based on relevant research, by Research conducted by Rakhmawati (2012). The study aimed to examine the influence of teacher teaching styles and the environment of teenagers association to the motivation of students' learning economic subjects on students of class XI IPS SMA Negeri 3 Tegal. With data analysis techniques using SPSS program.17. This research used simple linear regression analysis. From the results of this study can be seen that there is a significant influence between the teaching style of teachers to the students' learning motivation economy class XI IPS in SMA Negeri 3 Tegal. The equation with this research is to examine the influence of teacher's teaching style on student achievement. The difference is that there is a variable development of extracurricular activities. This matter reinforced with the results of research Rakhmawati (2012), the study aimed to examine the influence of teacher teaching styles and the environment of teenagers association to the motivation of students learning economic subjects on students class XI IPS SMA Negeri 3 Tegal. With data analysis techniques using SPSS.17 program. This research used simple linear regression analysis. From the results of this study, it can be seen that there is a significant influence between the teaching style of teachers to the students' learning motivation economy class XI IPS in SMA Negeri 3 Tegal. The equation with this research is to examine the influence of teacher's teaching style on student achievement.

Then research by Khuzaimah (2014) which aimed to determine the effect of teacher teaching style and student learning motivation on student achievement in accounting subjects. Using multiple linear regression analysis tools (t test) and using SPSS for WindowsVersion14.00 indicated that there was a significant influence between teacher teaching style and student learning motivation together on learning achievement. The equation with this research is to examine the influence of teacher teaching style and learning motivation on student achievement. The difference is there is no variable extracurricular activities.

Based on previous research, it can be concluded that student achievement has strong link with extracurricular activities, teacher teaching style and motivation. There is a significant positive influence on learning achievement. It also indicates that this learning activity is accepted by the students, teachers need trying to arise their interest in learning. Awakening the passion and interest in learning of the students will facilitate teachers in connecting teaching activities with learning activities. One form of passion is reflected in the motivation to learn. In this case motivation holds a dominant role. Therefore, the discussion of passion and interest in motivation to learn cannot be separated from the style or way of teaching teachers when they deliver subject matter. The more appropriate the teacher's style or way of teaching, the more chances of obtaining student learning outcomes which is in line with the greater expectations. Partial test for teacher teaching style variables showed that teacher teaching style variables have a significant influence on learning achievement variables.

\section{REFERENCES}

Abraham H. Maslow. 1984. Motivation and Needs. Jakara: PPM 
Algifari. 2000. Regression, Theory, Case and Solution Analysis. Yogyakarta: BPFE

Alimuddin S Miru. 2009. Relationship Between Motivation Learning Against Student Achievement Eye Training Electrical Installation Students SMK Negeri 3 Makassar. Thesis: UNM.

AmbElo Adam and Tolla Ismail. 1987. Fundamentals of Educational Administration. Cet. II; Ujung View: FIP IKIP.

Amin, Saiful, Dimyati, M., \& Firdaus, M. (2016). Pengaruh Citra Perusahaan Dan Citra Pemakai Terhadap Keputusan Pembelian Jasa Perbankan Syariah Di Jember. (1), 501-518. Retrieved from http://jurnal.stiemandala.ac.id/index.php/relasi/article/ view/90

Arikunto, Suharsimi. 1993. Teaching Management Humanely. Jakarta: RinekaCipta.

Atika Prama Deswita. 2013. Influence of Student Perception About Teachers Teaching Style and Student Learning Interest On Accounting Learning Outcomes In Accounting Expertise Program Student X Class at SMKN 1 Sawahlunto. Thesis: STKIP - PGRI West Sumatra.

Budiarti. 2014. The influence of school environment and student's learning motivation on student's economic achievement on student's economic achievement of class XI IPS SMA Negeri 2 Sukoharjo

Department of Education and Culture. 1987. Big Indonesian Dictionary.Jakarta: BalaiPustaka.

Dimyati and Mudjiono. 2009. Learning and Learning. Jakarta: RinekaCipta.

Ghozali. 2005. Quantitative And Qualitative Research Methods. Bandung: PT. RefikaAditama

Ghozali, Imam. 2006. Application of Multivariate Analysis with SPSS program. Semarang: UNDIP Publishing Agency.
Hamalik, Oemar. 2005. Teaching and Learning Process. Jakarta: Earth Literacy.

Marno\&Idris, M. 2008.Strategies and Teaching Methods. Yogyakarta: Ar. Ruz Media

Nasrudin, Roni. 2010. The Effect Of Student Participation In Extracurricular Activities Against Student Achievement Motivation SMK N 2 Garut. Thesis: UPI Bandung. http://isjd.pdii.lipi.go.id/admin/jurnal/ 142074954.pdf (October 8, 2016).

Nurhayati. 2013. The Effect of Extracurricular Activities Against the Achievement of Economics Student Learning Class X MA Darussalam Jombang. Thesis.

Permendiknas No.22 Year 2006.Guidelines for self-development.MinistryNational Education.

Prianto, Agus. 2008. Data Analysis WithSpss Program Version 15. Malang: Equivalent Press.

Priyatno, Duwi. 2009. 5 Hours of Learning Data with SPSS 17. Yogyakrta:Andi Offset.

Rakhmawati. 2012. Influence Teaching Style Teachers and Youth Affairs Environment Against Student Learning Moivasi Economics Lessons on Students Class XI IPS SMA Negeri3 Tegal. Thesis: UNS.

Santoso, Singgih. 2000. SPSS Exercise Book Parametric Statistics. 1st Print. Jakarta: PT. Elex Media Computindo

Sardiman, A.M. 2007. Interaction and Teaching Motivation Motivation. Jakarta: PT. Raja GrafindoPersada.

SudatiWinarni, 2014. Influence Teacher Attention, Learning Motivation, and Emotional Intelligence on Student Learning Achievement of Senior High School 2 Bantul. Thesis: BIOEDUKATIKA.

Sudjana, Nana. 2005. The Basics of Teaching and Learning Process. Bandung: SinarBaruAlgensindo. 
Sudjana, N. and Ibrahim. 2010. Research And Educational Assessment. Bandung: SinarBaruAlgensindo.

Sugiyono. 2012. Educational Research Method (Quantitative Approach, Qualitative, and R \& D). Bandung: CV. ALFABETA.

Sunaryo. 1989. Teaching and Learning Strategies in Social Sciences Teaching. Jakarta: Dekdikbud Directorate General of Higher Education Objectives Development of Educational Institution of Education Personnel.

Slameto. 2003. Learning and Factors Affecting It. Jakarta: PT. Rineka Cipta.

SinggihSantoso. 2004. SPSS multivariate statistics. Jakarta: PT Elex Media Komputindo

Shah Muhibbin. 1999. Educational Psychology with New Approach. Cet. IV Bandung: Youth Rosdakarya.

Syaiful Bahri. 2011. Learning Psychology. Jakarta: RinekaCipta.
Syamsudar, Bambang. 2012. Impact of Extracurricular Activities High frequency sports, Low and Extracurricular Activities Not Exercise on student learning outcomes SMM Santa Maria Bandung. In JurnalPendidikanUniversitasPendidika n Indonesia 2012.

Act of Sisdiknas 2003 (RI Law No. 20 of 2003). Jakarta: SinarGrafika.

Wahyudi. 2010. The Influence Of Student Motivation And Variation Of Teaching Style of Teachers To Student Achievement Student Learning Class Xi IpsSma Virgo Fidelis .Bawen: UNNES.

Winarni. 2014. Influence Teacher Attention, Learning Motivation and Emotional Intelligence simultaneously or partially to the Student Learning Achievement of Senior High School 2. Bantul: UNNES

W.S. Winkell. 2004. Educational Psychology and Learning Evaluation. Jakarta: Gramedia 